\title{
The Competent and Inter-Disciplinary Approach in Setting up Students' Independent and Science-Oriented Research Work (On the Example of Teaching "The History of the Ancient World")
}

\author{
Ludmila M. Shmelyova $^{1}$ \\ ${ }^{1}$ Kazan (Volga Region) Federal University, Kazan, Russia \\ Correspondence: Ludmila Mikhailovna Shmelyova, Kazan (Volga Region) Federal University, Kremlyovskaya \\ Street 18, Kazan 420008, Russia. E-mail: procella@rambler.ru
}

Received: April 14, 2015 Accepted: April 20, 2015 Online Published: April 27, 2015

doi:10.5539/jsd.v8n4p7 URL: http://dx.doi.org/10.5539/jsd.v8n4p7

\begin{abstract}
The following problem is acute owing to Russia's high school transition onto new federal state educational standards of high professional education and an increase of participation of students in independent and science-oriented research work within studying process. The article is aimed at generalization of application experience of the competent and inter-disciplinary approach in organizing independent and scientific research work within mastering the discipline "The History of the Ancient world". The chief approach towards investigating the following problem lies in a complex of historical and pedagogical investigation methods. The article shows the organization of students' independent and science-oriented research work within mastering the History of the Ancient world, a connection of kinds and forms of independent and science-oriented research work with a competent and inter-disciplinary approach to teaching and setting up students' independent and science-oriented research work. It has been discovered that combining the above mentioned approaches to setting up the work with students while mastering the discipline can improve the progress in studies, shape professional skills and the whole picture of a subject studied. The article material may be of high value for organizing independent and science-oriented work with students at historical disciplines.
\end{abstract}

Keywords: The History of the Ancient world, students' independent work, the student's science-oriented work, high school tutoring, the Federal state educational standards

\section{Introduction}

\subsection{Acuteness}

In connection with the Federal state educational standard being implemented in all the cycles of education: from pre-school up to high school, priorities in teaching alter into direction of an independent personality shaping, - the personality with developed abilities of decision-taking, decision-consequence estimating, the one with a good level of competence. In these conditions a modern History teacher's activity envisages a constantly growing number of possibilities of applying inter-disciplinary and competent approaches.

Therefore, would-be teachers should act not only within a historical field, but attract methods and data of other sciences to independent and science-oriented research work, acquire common cultural and professional competence - all this could enable them to become competitive specialists (Gromova, 2005).

Nowadays the science of History is an inter-disciplinary science which uses methodology and data of other sciences working at the junction of both humanities and natural sciences. It is particularly true about Ancient History teaching disciplines which involve methods and data of other sciences.

\subsection{The Federal State Educational Standard and the Competent Teaching Approach}

The Federal state educational standard for general secondary and full education is focused on students' getting personal results aimed at communication and self-monitoring skills mastering, meta-subject results which head for the whole-picture world perception and school programme subjects final mastering results (the Federal state educational standard of secondary education. The secondary (full) education, 2011).

The Federal state educational standard of secondary education ("Pedagogical education" direction) covers the bachelors' training in pedagogical, cultural and science-oriented research activity. Competent challenges any 
graduate student should be able to meet are vividly depicted in the Federal state educational standard of high professional education, respectively. As well as the skills of the competence sufficient for solving professional problems in future. (the Federal state educational standard of high professional education with direction of training 050100 Pedagogical education, Bachelor's degree, 2011).

Every discipline of the secondary education any student is to master has a range of competences. These are the competences students should focus their attention on within studying the direction "Pedagogical education" on the training profile "History and a foreign language (English)" while mastering "The History of the Ancient world":

The first unit - common cultural competences:

mastering mentality culture, ability to generalization, analysis and information perception, aim setting and a choice of ways of its achievement;

capability to analyze outlook, social and personality essential philosophic problems;

The second unit - common professional competences:

realizing the social importance of your future profession, having enough motivation for implementation of your professional activity;

The third unit - professional competences:

ability to work out and implement educational programmes of basic and elective courses in various educational establishments;

readiness to apply up-to-date techniques and technologies, diagnostic methods assisting in detecting students' achievements to prove a good quality of an educational process.

The above mentioned competences are oriented at the personality shaping of a History student as a would-be teacher. A competent approach envisages strengthening of student's independent work. In its turn the independent work can be a medium of competences shaping. A special attention should be drawn here to the formation of independent and science-oriented research skills within the work on the discipline studying "The History of the Ancient world".

\subsection{Exploring the Importance of the Problem}

A pedagogical comprehension of the current situation of the secondary school specialists' training has led to the search of new possibilities of using students' independent and science-oriented research work for the implementation of the Federal state educational standard of higher education and a competent approach in teaching as well.

Students' independent and science-oriented research work should abound in inter-disciplinary connections and a competent approach in teaching, along with the application of historical investigation methods.

In the context of students' training for studying the direction "Pedagogical education" on the training profile "History and a foreign language (English)" while mastering "The History of the Ancient world" we should construct independent and science-oriented research work in a way that it could form the students' whole vision of the subject studied and could shape them as would-be teachers (Grinchenko \& Kurdumanova, 2012).

\subsection{Status of a Problem}

Students' independent and science-oriented research work has been studied from different viewpoints. The status of modern higher education in Russia is highlighted in the works by E.L.Grinchenko, O.I.Kurdumanova (2012), N.N.Matushkina (2010), O.N.Korzhenevskaya (2013). Students' independent work setting up is considered in the works by O.N.Yefremova (2013), T.N.Ivleva (2012), I.N.Luchinina, T.V.Tikhomirova, I.S.Voroshilova, D.A.Romanova (2013). The application of the competent approach in educating and its implementation through students' independent and science-oriented research work has been underlined in the works by F.Sh.Galiullina (2011), A.A.Vlasenko, N.V.Soboleva, S.V.Sobolev, M.V.Marznenakova (2014), I.V.Sharf (2011).

The analysis of the above mentioned authors' works and other numerous publications on the problem of students' independent and science-oriented research work setting up in conditions of implementing the Federal state educational standard of the third generation has vividly shown that theoretical investigations on the problems of implementing the Federal state educational standard, the competent approach, students' independent and science-oriented research work setting up within the Federal state educational standard along with a competent and inter-disciplinary approach to natural and some social disciplines training setting up have been thoroughly overviewed. However, investigations reflecting these problems and approaches to teaching historical disciplines are missing - therefore, there comes up a necessity to analyze competent and inter-disciplinary approaches within 
implementing the Federal state educational standard of the third generation into teaching historical disciplines.

\section{Methodological Framework}

\subsection{Investigation Tasks}

In the course of investigations the tasks that have been fulfilled are as follows: 1) putting a competent and inter-disciplinary approach to studies within analyzing the Federal state educational standard of the third generation; 2) applying the received data for the analysis of students' independent and science-oriented research work within the training on the basis of the discipline "The History of the Ancient world"; 3) generalizing the received data, effective estimation of kinds and forms of students' independent and science-oriented research work.

\subsection{Theoretical and Empirical Methods}

For the sake of fulfilling the given tasks, a set of various mutually influencing methods has been used:

- theoretical - literature analysis, normative, legislative, instructive-methodical, studying the working documents and materials of monitoring and procession character on the investigation problems; studying and generalizing of innovative pedagogical experience, analysis, synthesis;

- empirical - inclusive observation, pedagogical experiment, testing, studying of the results of inside- and outside-university activity.

\subsection{Investigation Methodology}

Common principles of historiographical analysis have been used: the definition of an investigation complex of problems, the analysis of authors' theoretic-methodological positions. Aside from that, the following historical methods have been applied: comparative-historical, which enabled to estimate the authors' contribution into the development of the application problem of competent and inter-disciplinary approaches to teaching in high school bearing the requirements of the Federal state educational standard in mind; typological, owing to which the most essential for the chosen topic materials have been taken.

Meanwhile a number of pedagogical investigation methods have been applied. In the first turn they are traditional methods inherited by modern pedagogics from research-makers having started up the pedagogical science itself. These are methods of observation; experience, first-source, student creativity and a conversation investigation.

An observation - a specially organized perception of an object, process or phenomenon in its natural conditions studied. This method application gives a chance to form competences in the course of students' independent and science-oriented research work.

In the broad sense of the word an experience investigation is an organized cognitive activity aimed at the establishment of historical up-bringing bonds, singling out the common and fixed in educational systems. By means of this method, the ways of problem solving are analyzed, reasonable conclusions about their application expediency in new historical conditions are taken.

Studying student creativity - home tasks and class works, abstracts, source notes, contour maps filling on a discipline studied. This method helps to have a look at a real sample of students' independent work within studying the History of the Ancient world.

\section{Results}

\subsection{The Discipline "The History of the Ancient world"}

The discipline "The History of the Ancient world" is studied in the first year of university during two terms. In the first term the History of primeval society and Ancient Oriental History are studied, the second term dwells on the History of Ancient Greece and Ancient Rome - and both terms end in an exam. Students' independent work according to the Federal state educational standard falls onto a half of discipline hours - 108 hours, the auditorium half makes 108 hours, 72 hours of which are practical classes. In connection with this, a specter of tasks for students' independent work has been widened - in comparison with the previous standard. The following tasks have been included here: a practical class preparation (themes, additional literature, Internet-source links), source notes, contour maps filling, abstract writing, a test and exam preparation work.

Along with a total decrease of hours on the discipline from 378 to 216 in the Federal state educational standard of higher professional education of the third generation, the major part of the material falls onto independent studying.

Only common tendencies of the Ancient world several countries and regions development and their biggest problems are reviewed, a basic picture-building about possible inter-disciplinary connections and examples of their usage for getting final information given in course books and scientific research works are offered. Practical classes 
highlight large-scale themes, which make students study extra material. Dividing the training material is made in such a way that auditorium and independent work could not repeat each other, and simultaneously, could shape students' whole-picture vision of the Ancient world.

\subsection{The Application of the Point-Rating Estimation with Students' Knowledge on the Discipline "The History of the} Ancient world"

In connection with the point-rating estimation of students' knowledge implementation, all students' works on the discipline are estimated in points - both auditorium and out-of-class (independent) works.

A quantity of points saved by a student for carrying out different tasks during the term becomes a bottom-line at putting the final exam mark.

The following system of students' knowledge estimation has been worked out on the basis of the discipline teaching experience (in the under-going table there are points for one term):

Table 1. The point distribution depending on the task type

\begin{tabular}{llll}
\hline Types of students' work & $\begin{array}{l}\text { Quantity of points for } \\
\text { the given type of work }\end{array}$ & $\begin{array}{l}\text { How many times the given } \\
\text { type of work should be } \\
\text { fulfilled }\end{array}$ & $\begin{array}{l}\text { Maximal point quantity for } \\
\text { the given type of work per } \\
\text { one term }\end{array}$ \\
\hline $\begin{array}{l}\text { A detailed written answer } \\
\text { (notes for a practical }\end{array}$ & 0,3 & 18 & 5,4 \\
class) & & & 12,6 \\
A detailed oral answer at & 0,7 & 18 & 8 \\
a practical class & 1 & 8 & 3 \\
Contour maps & 1 & 3 & 10 \\
Source notes & 5 & 2 & 11 \\
Control work or test & 6,5 & 1 & \\
Abstract & & & \\
\hline
\end{tabular}

This knowledge estimation system lets students save a necessary amount of points (max. 50 points per the work during the term) and enables a teacher to choose the most effective types of independent work.

Students' knowledge control is carried out in the form of a test and an exam (max. 50 points).

The implementation of the Federal state educational standard of higher professional education and the point-rating system envisage an increase of the part of students' independent work, and its control accordingly. It stimulates students' careful fulfilling a range of independent tasks; it breeds a more hard-working attitude to a practical class preparation.

In general, the results of the system implementation (referring to the studies of the History of the Ancient world) have turned out to be positive. It is shown in both - students' attitude to the process of studying the History of the Ancient world, and their tidiness in task fulfilling, in altering the university studies motivation, which has been numerously confirmed by exam results.

\subsection{Students' Independent Work on the Discipline "The History of the Ancient world" and the Usage of the} Electronic Course "The History of the Ancient world"

Out-of-auditorium independent work on the discipline "The History of the Ancient world" can be divided into casual training and science-oriented research work.

The aims of students' independent work on the discipline "The History of the Ancient world" are as follows:

- learning to independently apply ways of work together with traditional sources of information, with Internet resources on History; to literally model computer texts;

- developing students' abilities in demonstrating basic knowledge in the field of History and forming the decision experience of professional task solutions on the basis of the received knowledge;

- evaluating students' professionally important personal traits - such as their own strategy choice, the responsibility 
for the decision taken, etc. (Golobokova, 2011).

Taking the formulated aims, competent and inter-disciplinary approaches into account, the tasks for students' independent work on the discipline "The History of the Ancient world" have been worked out.

These tasks for students are located on the electronic ground "Tulpar" of Kazan Federal University, the address is http:/tulpar.kfu.ru. The electronic course "The History of the Ancient world" can be found here: http:/tulpar.kfu.ru/course/view.php?id=541 and is accessible to registered users only. Practical class tasks are present here (themes, questions, literature, the order of preparation), tasks on source noting, contour maps filling, schemes of handing these works in, topics of abstracts and a requirement list of their making.

Let us point out the forms of students' independent work.

Within the electronic course "The History of the Ancient world" are presented the themes of practical classes, questions touched upon in class, chief and additional literature on the theme and extra materials (outer source links, extracts from sources, audio- and video-materials), the part of which is based on the inter-disciplinary approach usage. This set enables students to go through theme questions in full volume and give a good answer in class.

Students carry out the tasks on source noting and counter maps filling. These types of work head for the shaping of independent work skills with historical sources and historical maps.

Counter maps filling skills are aimed at the formation of map reading skills with students, the cartographic material usage in studying process, the ability of the historical map analyzing. These skills are essential both for the course material mastering and for further science-oriented research and pedagogical work (at History lessons the teacher should give his students basic ideas about the work with cartographic historical material). Therefore, counter map filling is also focused on students' mastering professional competences.

Source noting and counter maps are taken at the internal consultation. Students are enquired about the kind and contents of the source. The correctness of counter map filling is checked when they are handed in, students should explain fulfilled tasks on the map - it is aimed at stimulating independent work on the one hand, and the formation of common cultural competences, on the other.

Within the plan of realization of competent and inter-disciplinary approaches in studying, an abstract writing is seen as the form of independent work. The abstract written on the discipline "The History of the Ancient world" is to widen and deepen the knowledge on separate themes of the course studied.

In the electronic course methodical recommendations on abstract writing are given. They cover the stages of work preparation, peculiarities of this kind of independent student work. A demanding list to abstract modelling and samples are located in the electronic course and are always accessible to students. After writing an abstract the student sends it to the teacher to be checked, the latter makes remarks, gives comments and puts the mark. Students have a possibility to make necessary corrections on the basis of the teacher's remarks and present a new variant of their abstracts. This algorithm of the task fulfilling enables the student to understand the aim of the abstract writing, the rules of its modelling, peculiarities of the abstract as the form of the student's independent work. It is in the course of writing the work when the skills of analyzing information are developed, the aim-setting skills and the choice of ways of your aim-achievement, as well as the skills of giving a sound analysis of worldview, socially and personally important philosophic problems - what makes the formation of professional competences.

In addition to all this the electronic course "The History of the Ancient world" has extra materials for students' getting acquainted with the discipline themes - both the ones reviewed in class, and those that are supposed to be studied independently. These kinds of material are present in a few variants:

\section{1. lecture texts,}

2. separate files and links to Internet-resources.

Lecture work includes reading the lecture text and answering one or a couple of questions after each part and the whole lecture. This kind of students' independent work is also estimated in points which are reflected in summary tables. Besides, a part of files and links envisages obligatory studying and getting a tick for its fulfilling. It helps to see the way the student works and realize how well the lectures and extra materials are studied.

The system lets students ask questions in the forum in the form of personal messages addressed to the teacher. The teacher can check the student activity in the task fulfilling and the course-material studying in points. All the tasks are estimated in points - as well as forums. Students can watch their points anytime and the teacher has a possibility to look through summary tables with the task fulfilling information.

To sum it up, students' independent work on the discipline "The History of the Ancient world" includes several 
kinds of tasks and their check-up is carried out in the face-to-face or distant form which enables to give effective time-consuming both to students and the teacher. Aside from that, it helps to make a picture of the student activity in discipline studying and the task and theme fulfilling made for independent work.

\subsection{Students'Science-Oriented Research Work within Studying the Discipline "The History of the Ancient world"}

Writing abstracts (this kind of work combines both basic training and science-oriented research functions) and the course work making on the discipline "The History of the Ancient world" should be referred to as students' science-oriented research work.

The abstract as the kind of science-oriented research work envisages the generalization of materials and opinions on the given problem of the History of the Ancient world, as well as an independent narration of a problem on the basis of facts taken from sources and literature. Writing the abstract as a science-oriented research work puts forward the following aims in front of students: "A thoughtful theme choice, a bibliographic search, a selection and analysis of facts, attitudes and conclusions contained in scientific literature, their grouping, a logical narration in accordance with an author's plan and his / her own estimation, making a referral apparatus and modelling of the whole text" (Methodical brochure on monitoring the studying process, independent and scientific historical students' work, 2006).

The work over the abstract gives a possibility to acquire the skills of the search and analysis of historical sources and scientific literature, master the methods of making a research work and the preparation basis of a written scientific work. When working over the abstract inter-disciplinary approaches to a chosen theme investigation are greeted.

Therefore, the abstract as a research work facilitates the formation of common cultural and professional competences, as well as prepares students for mastering special competences when studying disciplines with senior year students.

The second kind of science-oriented research work - a course work on the discipline - contains elements of an independent research work; it is aimed at getting new knowledge as well. The course work is oriented at the formation of the skills of searching and analyzing scientific information in sources and literature, at the application of the received knowledge, skills while mastering the discipline "The History of the Ancient world"; at the usage of inter-disciplinary approaches while writing the work. An especially important role goes to the source investigating as long as we can speak about a research work in the direct meaning of the word.

The stages of the abstract and the course work preparations are similar in many ways. They have the following algorithm of actions:

The theme choice

Plan-making and reference-list constructing

Material collection

The source and scientific literature analysis

Writing a draft of the work

Making necessary corrections and additions

Modelling a final variant of the text

Following this step-by-step algorithm, the student masters mentality culture, the ability to generalize and analyze information, skills of aim-setting and the choice of its achievement ways, the ability to give a good analysis of worldview, socially and personally important philosophic problems; realizes the social importance of his future profession.

Fulfilling the course work focuses on the formation of competences, envisaged by the Federal state educational standard and is conducive to training Bachelors on the following preparation direction 050100 Pedagogical education "to the types of professional activity as follows: pedagogical; cultural; science-oriented research" (the Federal state educational standard of the higher education Pedagogical education).

\section{Discussions}

Some aspects of the problem studied have been reviewed in publications of domestic scientists and teachers. We can single out the following clusters of publications:

research works dedicated to the state of modern high and secondary schools (Grinchenko \& Kurdumanova, 2012; Matushkin, 2010; Korzhenevskaya, 2013); 
research works dedicated to studying the application of inter-disciplinary approaches in teaching (Rykun \& Savin, 2013; Nikitin, 2010; Gromova, 2005);

the works considering the questions of monitoring students' independent and science-oriented research work and their influence on the formation of students' professional competences (Galiullina, 2011; Shmelyova, 2008; Shmelyova, 2010; Shmelyova, 2012; Vlasenko, Soboleva, Sobolev \& Marzhenakov, 2014; Sharf, 2011, etc.).

However, the problems of the application of competent and inter-disciplinary approaches on the example of historical disciplines are rarely investigated in articles telling about the questions of monitoring students' independent and research work. These articles dwell on theoretical background or just describe the application of the given approaches to studying natural and some social disciplines.

In connection with all this appears a necessity of investigating an organization of students' independent and research work from the point of view of the professional competences formation and students' using inter-disciplinary approaches in relation to historical disciplines mastering.

\section{Conclusion}

The offered in the article contents of students' independent and research work on the discipline "The History of the Ancient world" and the point-rating estimation of students' knowledge on the discipline "The History of the Ancient world" go together with the following principles: the correspondence of contents of students' independent and research work with the contents of training of a History teacher or a History specialist, with a union of the content and process side of teaching; with the content which aims at meeting qualification requirements; with a balance of the training content and basic types of a specialist's professional activity. Students' independent and research work on the discipline "The History of the Ancient world" consists of studying monographs, collecting and analyzing sources and literature which are essential for practical classes, making necessary notes and extracts, writing ready-made answers to certain questions of their plan, abstract writing, putting sources down, counter maps filling, test preparing and - finally, exam-taking on the discipline. Meanwhile teaching "The History of the Ancient world", students' independent work is estimated in points and it enables students to realize the level of mastering of this or that type of independent work. The communicative possibilities of the electronic course "The History of the Ancient world" can help to get the teacher's consultation on possible questions. In general, the system lets the student master the discipline material "The History of the Ancient world", is conducive to shaping proper competence skills which are recommended by the Federal state standard and the basic educational programme, and aims at forming a successful and modern History teacher.

\section{Acknowledgments}

The work is performed according to the Russian Government Program of Competitive Growth of Kazan Federal University.

\section{References}

Dyatlova, K. D., \& Kolpakov I. A. (2012). Samostoyatel'naya rabota studentov kak sposob formirovaniya kompetentzii. Vestnik Nizhegorodskogo universiteta imeni N.I. Lobachevskogo, 1(1), 25-29.

Federal'niy gosudarstvenniy obrazovatel'niy standart obshchego obrazovaniya. Sredneye (polnoye) obshcheye obrazovaniye. (2011). Moscow.

Federal'niy gosudarstvenniy obrazovatel'niy standart vysshego professional'nogo obrazovaniya. Pedagogicheskoye obrazovaniye. Retrieved from http://fgosvo.ru/uploadfiles/fgos/5/20111207164014.pdf

Galiullina, F. S. (2011). Nauchno-issledovatel'skaya deyatel'nost' studentov kak faktor formirovaniya professional'noy kompetentzii. Vestnik Tatarskogo gosudarstvennogo gumanitarno-pedagogicheskogo universiteta (TSHPU Bulletin), 3(25), 235-239.

Golobkova, G. I. (2011). Samostoyatel'naya rabota studentov v bakalavriate po napravleniyu podgotovki Pedagogicheskoye obrazovaniye. Uchyonye zapiski Zabaikal'skogo gosudarstvennogo gumanitarno-pedagogicheskogo universiteta imeni N.G. Chernyshevskogo, 6, 72-77.

Grinchenko, E. L., \& Kurdumanova, O. I. (2012). Osobennosti prepodavaniya chimii na farmatzevticheskom fakultete v svyazi s perekhodom na noviye standarti vysshego professional'nogo. Omsky nauchny vestnik, 2(114), 32-33.

Gromova, N. M. (2005). Integrativnyi mezhdistziplinarnyi podkhod v izuchenii ekonomiki pri podgotovke sovremennyh spetzialistov. Fundamental'nye issledovaniya (Fundamental Research), 1, 98-99.

Ivleva, T. N. (2012). Interaktivniye metody obucheniya v organizatzii samostoyatel'noy raboty studentov. Vestnik 
Kemerovskogo gosudarstvennogo universiteta kul tury i iskusstv, 21, 145-150.

Korzhenevskaya, O. N. (2013). Sovremennaya vysshaya shkola: vyzovy I napravleniya razvitiya. Izvestiya Volgogradskogo gosudarstvennogo tekhnicheskogo universiteta. 11 (114). Vol. 16: 9-17.

Luchinina, I. N., Tikhomirova, T. V., Voroshilova, I. S., \& Romanov, D. A. (2013). Monitoring samostoyatel'noy raboty studentov (Ucheniye zapiski universiteta imeni P.F. Lesgafta), 11 (105), 90-93.

Matushkin, N. N. (2010). Sovershenstvovaniye obrazovatel'noy sredy universiteta. Vyssheye obrazovaniye v Rossii, 5, 81-86.

Metodicheskoye posobiye po organizatzii uchebnogo protzessa, samostoyatel'noy i nauchnoy raboty studentov istoricheskih fakul'tetov: metodicheskiye rekommendatzii studentam dnevnyh i zaochnyh otdeleniy. (2006). Kazan.

Nikitin, P. V. (2010). Primeneniye mezhdistziplinarnogo podkhoda v obuchenii budushchikh uchiteley informatiki. Obrazovatel'niye tekhnologii I obshchestvo (Educational Technology \& Society). V.13. 1: 416-427.

Rykun, M. P., \& Savin, P. N. (2013). Mezhdistziplinarniye podkhody v prepodavanii fizicheskoy antropologii na gumanitarnyh fakul'tetah. Vestnik Tomskogo gosudarsstvennogo universiteta. Istoriya 4/24: 23-26.

Sharf, I. V. (2011). Realizatziya samostoyatel'noy raboty studentov v kompetentnostnoy modeli. Vyssheye obrazovaniye v Rossii, 6, 98-103.

Shmelyova, L. M. (2008). Primeneniye ball'no-reytingovoy sistemy v kurse "Istoriya drevnego mira" v Tatarskom gosudarstvennom gumanitarno-pedagogicheskom universitete. Problema kachestva istoricheskogo obrazovaniya v sisteme vysshey shkoly, 208-210.

Shmelyova, L. M. (2010). Prepodavaniye istorii drevnego mira v usloviyah modernizatzii vysshego obrazovaniya (na primere Tatarskogo gosudarstvennogo gumanitarno-pedagogicheskogo universiteta). Istoricheskoye obrazovaniye $\mathrm{v}$ vysshey shkole: formirovaniye spetzialista $\mathrm{i}$ grazhdanina: Materialy Vserossiyskoi nauchno-prakticheskoi konferentzii, Kazan, December 9-10 2010 Kazan, 2010: 190-193.

Shmelyova, L. M. (2012). Samostoyatel'naya rabota studentov v ramkah izucheniya distzipliny "istoriya drevnego mira" (v sootvetstvii s trebovaniyami Federal'nogo gosudarstvennogo obrazovatel'nogo standarta vysshego professional'nogo obrazovaniya tret'yego pokoleniya). Istoricheskaya nauka I obrazovaniye $\mathrm{v}$ usloviyah sovremennyh vyzovov: Materialy mezhdunarodnoi nauchno-prakticheskoi konferentzii, Kazan, November 22-23 2012. Kazan, 2012: 217-219.

Vlasenko, A. A., Soboleva, N. V., Sobolev, S. V., \& Marzhenakov, M. V. (2014). Kompetentnostny podkhod k sovershenstvovaniyu samostoyatel'noi raboty studentov. Fundamental'nye issledovaniya (Fundamental Research), 9-10, 2298-2302.

Yefremova, O. N. (2013). Opyt organizatzii samostoyatel'noy raboty studentov. Vyssheye obrazovaniye v Rossii, $8-9,160-162$.

\section{Copyrights}

Copyright for this article is retained by the author(s), with first publication rights granted to the journal.

This is an open-access article distributed under the terms and conditions of the Creative Commons Attribution license (http://creativecommons.org/licenses/by/3.0/). 